\title{
The Impact of Hockey Coaches and Team Cohesion on the Performance of Players
}

\author{
Abd Rahim Bin Mohd Shariff ${ }^{1}$, Saeed Javed ${ }^{1} \&$ Norkhalid Salimin $^{1}$ \\ ${ }^{1}$ Faculty of Sport Science and Coaching, Sultan Idris Education University, Tanjong Malim, Perak, Malaysia \\ Correspondence: Abd Rahim Bin Mohd Shariff, Faculty of Sport Science and Coaching, Sultan Idris Education \\ University, 35900 Tanjong Malim, Perak, Malaysia. E-mail: abd.rahim@fsskj.upsi.edu.my
}

Received: December 30, 2015 Accepted: January 18, $2016 \quad$ Online Published: March 18, 2016

doi:10.5539/ass.v12n4p74

URL: http://dx.doi.org/10.5539/ass.v12n4p74

\begin{abstract}
The primary objective of the existing paper deals with to examine the relationship of hockey coaches and team cohesion with the performance of field hockey players of Pakistan and their impact on players' performance. However the secondary objective was to measure the field performance of hockey players on practical measures. The research methodology is based on both descriptive and inferential statistical approaches. The descriptive data was collected in the form of field performance tests (technical skills and fitness capabilities) while the inferential data perceived by players was collected using survey questionnaire. A number of 296 national field hockey players of Pakistan were selected from 14 national departments of field hockey as samples. Descriptive statistics, correlation and multiple regression analysis were employed through SPSS (version 21.0). The results of the field performance tests were found below than average (weaker) in technical skills and fitness capabilities of national field hockey players of Pakistan. However, the findings of the inferential analysis revealed that hockey coaches and team cohesion have positive and significant relationships with the performance of field hockey players. Implications of existing study were also briefed.
\end{abstract}

Keywords: hockey coaches, team cohesion, player performance, Pakistan

\section{Introduction}

This may be wrong to guess that every sport in this advance epoch meets itself in a passionate competition milieu and is striving persistently to find the place wherever it can be fanfare successfully. This nontoxic capacity may be exposed in one or all areas of sports if the performances can be successfully carried. Pakistan dominated World field hockey during the 1980s, when they were the Asian, Olympic, and World champions. However, there has been a sharp decline in the performance of team Pakistan since the time of mid 1990s and the Pakistani team has not won any significant event at an international level. Meulmana, Berger, Zande, Kok, Ottevanger, and Crucq (2012) pointed out that particularly young field hockey players have troubled during training the modern era techniques, and therefore, they have not the victory experience required to raise the value of the training. Thiel, Tremaynea, and James (2012) expressed that the sport demands the expertise of ball control, stick rapidity, striking power, and dribbling quickness.

In this modern era, field hockey players are determinedly fronting the advanced challenges to prove their performance in this competitive sport world. They have to retort quickly due to scientific modifications, worldwide competition, and swift geographic alterations. The coaching environment may limit the opportunity for the performance efficiencies with the counterpart of cohesiveness of field hockey players is now become the emergent and critical challenge confronting by sport institutions. Several studies establish worldwide that hockey coaches and team cohesion are accepted as dynamic factors for the successful performance of players (Turman, 2008; Vincer \& Loughead, 2010; Westre \& Weiss, 1991). This is worst bad time with Pakistani field hockey that, even, the four (4) times world cup winner team could not qualify for the $13^{\text {th }}$ world cup held in Netherlands 2014 (Bhatti, 2013; Yaqoob, 2013; Zaman, 2013). Even though, the three (3) times Olympics champion Pakistan since its existence for first time in the history of Olympic Games could not qualify for the RIO Olympics 2016 (Zuberi, 2015).

\subsection{Literature Review}

Indeed, a number of research studies have defined about social factors particularly coaches (Murray, 2006) who 
have maximum interacted with the players and secondly team cohesion in which players have interactions among each other and stick together (Carron, Brawley, \& Widmeyer, 1998). It may be useless to estimate that coaching influences to players is very dynamic for a sport to elaborate. Nowadays, sport coaching is not almost the primary matter but also about fortifying players' gratification, devotion, and utmost prominently upholding a long-term coach-players relationship (Cottingham, Blom, Burchell, \& Johnson, 2010; Jowett, 2005). The fundamental of field hockey success has constantly been the capability to meet the best, thorough information, and to know and carry out the possibilities as exactly and rapidly as possible on the field of play by the players (Elferink-Gemser, Visscher, Lemmink, \& Mulder, 2007). The team cohesion among players embraces that the field hockey success may be achieved by the willpower of the players through target competitions.

From the last two decades, field hockey of Pakistan has suffered with severe decline due to several causes of their failure. Regardless the various deficiencies, the most central reason is poor fitness levels of the national field hockey players of Pakistan and the cause of instable performance as well (Haq, 2013). Zaman (2015) also pointed out that Pakistani national players' fitness had found very poor. The importance was not assumed to improving three main areas of fitness where the players deficiency severely. These main areas of fitness are also known as 3s, those computations for "stamina, speed, and skill" (Ali, 2015). Pakistan hockey team is requiring speed and strength that are indispensable components for enhanced performance in a mega event (Zaman, 2015). Presently, the existing field hockey coaches of Pakistan are not fully equipped with the up-to-date techniques that may boost the players' fitness level compare to international arena (Ali, 2015). Zaman (2015) declared that the continuously changing coaches since 2013 had been remained one of the central causes of the decline in Pakistan hockey. Moreover, changing the coaches often remains the teams incapable to approach the anticipated results.

Literature on sport coaches had acknowledged that there are many in which coaches are influenced in several ways but three primary approaches are most central (Jowett, 2007) on which the current structure is created, coach characteristics, coach expertise, and coach leadership. In coach characteristics approach, Forsyth (2010) described that the individual who appears to lead the team in sport is normally the one who is the utmost hardworking, knowledgeable, social, intellectual, flexible, and proficient (p. 262). The coach expertise, Jowett (2007) highlighted that coaches' target is to generate an environment in which players can obtain the technical, tactical, and strategically skills required for success in both individual and team sport (p. 63). The coach leadership viewpoint claims that having leadership skills is indeed one of significant essentials of an energetic and successful coach and leaders are considered as team members and they ratify a major role in team dynamics (Hoption, Phelan, \& Barling, 2007, p. 47; Khalaj, Khabiri, \& Sajjadi, 2011). On the other hand, regardless of these approaches, team cohesion (Carron, Shapcott, \& Burke, 2007a) is overlapping in these three approaches of coaches that may influence on the performance of players subsequently (Asghar, 2011).

Carron et al., (1998) developed the description of cohesion as "a dynamic process that is reflected in the tendency for a group to stick together and remain united in the pursuit of its instrumental objectives and/or for the satisfaction of member affective needs" (p. 213). Team cohesion is obviously an anticipated characteristic and it is not essential to perform well as a team but remain cohesive however not devoted for excellent performance level (Aoyagi, Cox, \& McGuire, 2008). Sport coaches can perform an energetic role in constructing the relations only through developing comprehensiveness of altogether team players in task-related circumstances for instance, during practice the skills and in social-related circumstances for example, during team gatherings or visits (Martin, Paradis, Eys, \& Evans, 2013). Cohesion always remained a part of attention in the individual and team levels of sports together (Shapcott, Carron, Greenlees, \& Hakim, 2010). The importance of cohesion in sports points out the relationship between team cohesion and sport success (Jowett \& Chaundy, 2004). Ramzaninezhad and Keshtan (2009) confirmed that extent of cohesion ensured an intense influence on the achievements of the team.

Numerous prior studies have been proven the positive and significant relationship between team cohesion and the performances of players (Alemu \& Babu, 2012; Beal, Cohen, Burke, \& McLendon, 2003; Brawley, Carron, \& Widmeyer, 1993; Bray \& Whaley, 2001; Carron \& Chelladurai, 1981a; Carron, Bray, \& Eye, 2002; Carron, Colman, Wheeler, \& Stevens, 2002; Chang, Duck, \& Bordia, 2006; Jacob \& Carron, 1998; Manning, 2007; Murray, 2006; Mullen \& Copper, 1994; Mohd Zainal \& Rosli, 2012; Williams \& Widmeyer, 1991; Eys, Ohlert, Evans, Wolf, Martin, Bussel, \& Steins, 2015). Murray (2006) study analysis revealed significant relationship between team cohesion and performance. In addition, Kanchan et al., (2012) study revealed the significant relationship of team cohesion and performance in ball games (basketball, football and volleyball). A study conducted by Chang et al. (2006) revealed that cohesion among players and performance would enhance over time. 


\subsection{Objectives of the Study}

The classification of substantial factors as hockey coaches and team cohesion that have straightly association on the performance of field hockey players would needed to be discovered.

i. To investigate to what extent are Pakistani field hockey institutions emerging in Pakistani hockey players and the measurement of players' performance needed to be successful in field hockey profession.

ii. To examine the relationship of hockey coaches and team cohesion with the performance of field hockey players of Pakistan.

iii. To examine the relationship between predictor factors (hockey coaches and team cohesion) and the performance of field hockey players of Pakistan

\subsection{Research Hypotheses}

To achieve the objectives of the present study, these subsequent hypotheses happen to be engineered.

H1: There is a positive relationship of hockey coaches and team cohesion with the performance of field hockey players of Pakistan.

H2: There are positive relationship between predictor factors (hockey coaches and team cohesion) and the performance of field hockey players of Pakistan.

\section{Method}

The suctions and sub-section of research method comprised of: a) participants of the study; b) sampling procedures; c) measurement methods; d) research design. All the sections and sub-section are described below subsequently.

\subsection{Participant Characteristics}

The participants of the study were national field hockey players overall Pakistan belonging to 14 national institutions. All national institutions were affiliated with Pakistan Hockey Federation (PHF) and were regularly participated in National Games of Pakistan. The participants of the study were engaged in dual methods of data collection through survey questionnaires and field performance tests.

\subsection{Sampling Procedures}

The researcher employed two sampling procedures for the current study known as purposive sampling and convenient sampling. All active field hockey players of sports institutions who had participated in National Games or National Championship, conditionally, were eligible to participate in the current study. Based on this specific purpose, the researcher used purposive sampling for the participants of the current study. Secondly, the most of the National field hockey departments and units' players were engaged in their trainings camps. The available players who willingly wanted to participate in the study without any pressure for participation considered for data collection. For this specific determination, the researcher used convenient sampling as well for the current study.

\subsubsection{Sample Size, Power, and Precision}

According to the statistics of Pakistan Hockey Federation (PHF, 2013), the strength of active field hockey players was 3207, who had participated in National Games and National Championship, considered as population of the current study. In view of the population, the researcher selected 510 field hockey players as samples of the 14 field hockey departments. According to Krejcie \& Morgan (1970), if population is in the figure of 3500, then the sample size should be comprised of 346 respondents. Tabachnick and Fidell (2001, p. 117) put a formula for computing requirements of sample size in view of the number of independent variables that is consisted of: $\mathrm{N}>50+8 \mathrm{~m}$ (where $\mathrm{m}=$ number of independent variables). However, the current study has two (2) independent variables according to Tabachnick and Fidell, 66 respondents are required while 510 samples considered a larger sample size for the current study.

\subsection{Measures and Covariates}

The existing study employed two instruments for data collection; survey questionnaire and field performance tests. First, the survey questionnaire was built up to find answers to empirical research questions of the study. The different scales for survey questionnaire, suitable to the study, were adapted with the permission of different researchers (Carron, Widmeyer, \& Brawley, 1985; Chelladurai \& Saleh, 1980; DeWeese, 2012). Every possible effort is utilized to uphold the questionnaire understandable, informal, and concise to increase response rate and keeping in view of the mentality of the respondents. Secondly, field performance tests were adopted by Pakistan 
Hockey Federation (PHF, 2013).

\subsubsection{Group Environment Questionnaire (GEQ)}

Group Environment Questionnaire was developed by Carron et al. (1985) comprised of 18 items. Responses were noted by encircling the given options through strongly disagree (SD) ... strongly agree (SA).

\subsubsection{The Leadership Scale for Sport (LLS)}

The Leadership Scale for Sport was developed by Chelladurai and Saleh (1980). The scale comprised of 40 items. The responses were indicated by encircling the provided options through Likert scale as strongly disagree (SD) ... strongly agree (SA).

\subsubsection{Sport Coaching Scale}

The Coaching Scale was designed by DeWeese (2012) to understand and examine the coaches' behaviors perceived by the national field hockey players about their coaches. The responses were noted by encircling the given options by Likert scale as strongly disagree (SD) ... strongly agree (SA).

\subsubsection{Field Performance Tests}

Field performance tests were designed by Pakistan Hockey Federation (2013) comprised of technical skills and fitness capabilities. These tests were conducted in fields of play practically. It was compulsory for those field hockey players who filled the survey questionnaires to participate in field performance tests as well.

\subsubsection{Procedure of Data Collection}

The survey questionnaires were distributed among 510 field hockey players at the time scheduled. A short introduction of the study and its objectives were highlighted in the questionnaire covering page. The respondents were told that they may go to their homes with the survey questionnaires and report on next day for field performance tests with filled questionnaires. The field performance tests were measured by three field hockey experts (ex. Olympians) in the fields of play and their participation in the study was totally free of charge and willingly. However, 296 dependents were responded and reported on venues for field performance tests. In this regard, seven cities of Pakistan were selected as Lahore, Faisalabad, Gojera, Rawalpindi, Islamabad, Karachi, and Peshawar for data collection. Some of the players sent their filled survey questionnaires. Those, who filled only survey questionnaires and did not participate in field performance tests, were excluded from the analysis.

\subsection{Research design}

The design of the present study was planned for this survey research grounded on correlational (Aron, Aron, \& Coups, 2014) method. The method acknowledged in current study is quantitative survey research method. Quantitative method copes with a self-administered survey questionnaire to examine the research questions theoretically and field performance tests to examine the technical skills and fitness capabilities of field hockey players practically.

\section{Results}

\subsection{Statistics and Data Analysis}

The table below shows the Pearson's correlation coefficient results among hockey coaches, team cohesion, and the performance of field hockey players. The results revealed that hockey coaches had a highly strong and positive relationship $(r=.86)$ with the performance of field hockey players. Secondly, the result revealed that team cohesion had also highly strong and positive relationship $(r=.81)$ with the Performance of Field Hockey Players. Whereas both independent variables (hockey coaches and team cohesion) had an accurate and strong relationship $(r=.70)$ among each other (Cohen, Manion, \& Morrison, 2007; Muijs, 2011) which shows that no multicollinearity existed in the data. All the relationships are found significant at 5\% level of significance in Table 1.

Table 1. Correlation among all variables

\begin{tabular}{|c|c|c|c|c|}
\hline \multicolumn{2}{|c|}{ Variable } & \multirow{2}{*}{$\begin{array}{c}\text { Hockey Coaches } \\
1\end{array}$} & \multirow{2}{*}{ Team Cohesion } & \multirow[t]{2}{*}{ Performance of Field Hockey Players } \\
\hline & Pearson Correlation & & & \\
\hline \multirow[t]{2}{*}{ Hockey Coaches } & Sig. (2-tailed) & & & \\
\hline & $\mathrm{N}$ & 296 & & \\
\hline
\end{tabular}




\begin{tabular}{ccccc}
\hline & Pearson Correlation & $.704^{* *}$ & 1 \\
Team Cohesion & Sig. (2-tailed) & .000 & \\
& $\mathrm{~N}$ & 296 & 296 & 1 \\
\hline Performance of Field & Pearson Correlation & $.861^{* *}$ & $.810^{* *}$ & .000 \\
Hockey Players & Sig. (2-tailed) & .000 & 296 \\
\hline
\end{tabular}

** Correlation is significant at the 0.01 level (2-tailed).

The multiple regression result of Table 2a shows the dependence of the performance of field hockey players (tactical skills) on hockey coaches and team cohesion. The value of R-Square 0.609 which reveals there is $60.9 \%$ variance in the performance of field hockey players (tactical skills) is due to hockey coaches and team cohesion. The results of ANOVA depicted the value of $F(2,293)=228.232$ and $P$-value $=.000$ that these values were highly strong and statistically significant as shown in Table 2a.

Table 2(a). Impact of hockey coaches and team cohesion on the performance - tactical skills (model 1)

\begin{tabular}{cccccc}
\hline $\mathrm{R}$ & R Square & $\begin{array}{c}\text { Adjusted R } \\
\text { Square }\end{array}$ & Df & $\begin{array}{c}\text { ANOVA } \\
\mathrm{F}\end{array}$ & Sig. \\
\hline $.780^{\mathrm{a}}$ & .609 & .606 & 2,293 & 228.232 & $.000^{\mathrm{b}}$ \\
\hline
\end{tabular}

a. Predictors: (Constant), Team Cohesion, Hockey Coaches

b. Dependent Variable: Performance of Field Hockey Players (Tactical Skills)

The results of coefficients investigated that standardized coefficients of hockey coaches was ( $\beta=.426), t(8.279)$, $p=0.000$ and team cohesion $(\beta=.420), t(8.168), p=0.000$ on the performance of field hockey players (tactical skills) as shown in Table $2 \mathrm{~b}$. All the values of $\beta, t$, and $p$ of hockey coaches and team cohesion, showed the highly significant results as shown in table below.

Table 2(b). Impact of hockey coaches and team cohesion on the performance - tactical skills (model 1)

\begin{tabular}{|c|c|c|c|c|c|c|c|}
\hline \multirow{2}{*}{ Variables } & \multicolumn{2}{|c|}{$\begin{array}{l}\text { Unstandardized } \\
\text { Coefficients }\end{array}$} & \multirow{2}{*}{$\begin{array}{c}\begin{array}{c}\text { Standardized } \\
\text { Coefficients }\end{array} \\
\text { Beta }\end{array}$} & \multirow{2}{*}{$\mathrm{T}$} & \multirow{2}{*}{ Sig. } & \multicolumn{2}{|c|}{ Collinearity Statistics } \\
\hline & $\mathrm{B}$ & Std. Error & & & & Tolerance & VIF \\
\hline Hockey Coaches & .067 & .008 & .426 & 8.279 & .000 & .505 & 1.981 \\
\hline Team Cohesion & .243 & .030 & .420 & 8.168 & .000 & .505 & 1.981 \\
\hline
\end{tabular}

a. Dependent Variable: Performance of Field Hockey Players (Tactical Skills)

The multiple regression result of table 3a below shows the dependence of the performance of field hockey players (interpersonal skills) on hockey coaches and team cohesion. The value of R-Square 0.722 which reveals there is $72.2 \%$ variance in the performance of field hockey players (interpersonal skills) is due to hockey coaches and team cohesion. The results of ANOVA depicted the value of $F(2,293)=380.364$ and $P$-value $=.000$ that these values were highly strong and statistically significant as shown in Table $3 \mathrm{a}$.

Table 3(a). Impact of hockey coaches and team cohesion on the performance - interpersonal skills (model 2)

\begin{tabular}{cccccc}
\hline $\mathrm{R}$ & R Square & $\begin{array}{c}\text { Adjusted R } \\
\text { Square }\end{array}$ & Df & $\begin{array}{c}\text { ANOVA } \\
\text { F }\end{array}$ & Sig. \\
\hline $.850^{\mathrm{a}}$ & .722 & .720 & 2,293 & 380.364 & $.000^{\mathrm{b}}$ \\
\hline
\end{tabular}

a. Predictors: (Constant), Team Cohesion, Hockey Coaches

b. Dependent Variable: Performance of Field Hockey Players (Interpersonal Skills) 
The results of coefficients investigated that standardized coefficients of hockey coaches was $(\beta=.558), t(12.872)$, $p=0.000$ and team cohesion $(\beta=.359), t(8.273), p=0.000$ on the performance of field hockey players (interpersonal skills) as shown in Table $3 \mathrm{~b}$. All the values of $\beta, t$, and $p$ of hockey coaches and team cohesion, showed the highly significant results as shown in table below.

Table 3(b). Impact of hockey and team cohesion on the performance - interpersonal skills (model 2)

\begin{tabular}{|c|c|c|c|c|c|c|c|}
\hline \multirow{2}{*}{ Variables } & \multicolumn{2}{|c|}{$\begin{array}{l}\text { Unstandardized } \\
\text { Coefficients }\end{array}$} & \multirow{2}{*}{$\begin{array}{c}\begin{array}{c}\text { Standardized } \\
\text { Coefficients }\end{array} \\
\text { Beta }\end{array}$} & \multirow[t]{2}{*}{$\mathrm{t}$} & \multirow{2}{*}{ Sig. } & \multicolumn{2}{|c|}{$\begin{array}{c}\text { Collinearity } \\
\text { Statistics }\end{array}$} \\
\hline & $\mathrm{B}$ & Std. Error & & & & Tolerance & VIF \\
\hline Hockey Coaches & .108 & .008 & .558 & 12.872 & .000 & .505 & 1.981 \\
\hline Team Cohesion & .254 & .031 & .359 & 8.273 & .000 & .505 & 1.981 \\
\hline
\end{tabular}

a. Dependent Variable: Performance of Field Hockey Players (Interpersonal Skills)

The multiple regression result of table 4a shows the dependence of the performance of field hockey players (communication skills) on hockey coaches and team cohesion. The value of R-Square 0.707 which reveals there is $70.7 \%$ variance in the performance of field hockey players (communication skills) is due to hockey coaches and team cohesion. The results of ANOVA depicted the value of $F(2,293)=353.666$ and $P$-value $=.000$ that these values were highly strong and statistically significant as shown in Table 4a.

Table 4(a). Impact of hockey coaches and team cohesion on - communication skills (model 3)

\begin{tabular}{cccccc}
\hline $\mathrm{R}$ & $\mathrm{R}$ Square & $\begin{array}{c}\text { Adjusted } \mathrm{R} \\
\text { Square }\end{array}$ & Df & $\begin{array}{c}\text { ANOVA } \\
\mathrm{F}\end{array}$ & Sig. \\
\hline $.841^{\mathrm{a}}$ & .707 & .705 & 2,293 & 353.666 & $.000^{\mathrm{b}}$ \\
\hline
\end{tabular}

a. Predictors: (Constant), Team Cohesion, Hockey Coaches

b. Dependent Variable: Performance of Field Hockey Players (Communicational Skills)

The results of coefficients investigated that standardized coefficients of hockey coaches was $(\beta=.539), t(12.118)$, $p=0.000$ and team cohesion $(\beta=.369), t(8.293), p=0.000$ on the performance of field hockey players (communication skills) as shown in Table $4 \mathrm{~b}$. All the values of $\beta, t$, and $p$ of hockey coaches and team cohesion, showed the highly significant results as shown in table below.

Table 4(b). Impact of hockey coaches and team cohesion on the performance - communication skills (model 3)

\begin{tabular}{ccccccccc}
\hline \multirow{2}{*}{ Variables } & \multicolumn{2}{c}{$\begin{array}{c}\text { Unstandardized } \\
\text { Coefficients }\end{array}$} & $\begin{array}{c}\text { Standardized } \\
\text { Coefficients }\end{array}$ & \multirow{2}{*}{$\mathrm{T}$} & \multicolumn{2}{c}{ Sig. } & \multicolumn{2}{c}{ Collinearity Statistics } \\
\cline { 2 - 4 } & $\mathrm{B}$ & Std. Error & Beta & & & Tolerance & VIF \\
\hline Hockey Coaches & .090 & .007 & .539 & & 12.118 & .000 & .505 & 1.981 \\
Team Cohesion & .224 & .027 & .369 & & 8.293 & .000 & .505 & 1.981 \\
\hline
\end{tabular}

a. Dependent Variable: Performance of Field Hockey Players (Communicational Skills)

\subsection{Ancillary Analyses}

Table 5. Statistics technical skills of field hockey players

\begin{tabular}{ccccccc}
\hline & & Dribbling & Passing & Receiving & Hitting & Scoop \\
\hline $\mathrm{N}$ & 296 & 296 & 296 & 296 & 296 \\
& Valid & 3.10 & 2.66 & 2.88 & 2.72 & 2.96 \\
& Mean & .635 & .607 & .749 & .633 & .675 \\
\hline
\end{tabular}


Technical skills in shape of five (dribbling, passing, receiving, hitting, and scoop the ball practically) skills were evaluated in the field through performance tests as an alternative tool for data collection from the same respondents who participated in the survey questionnaire.

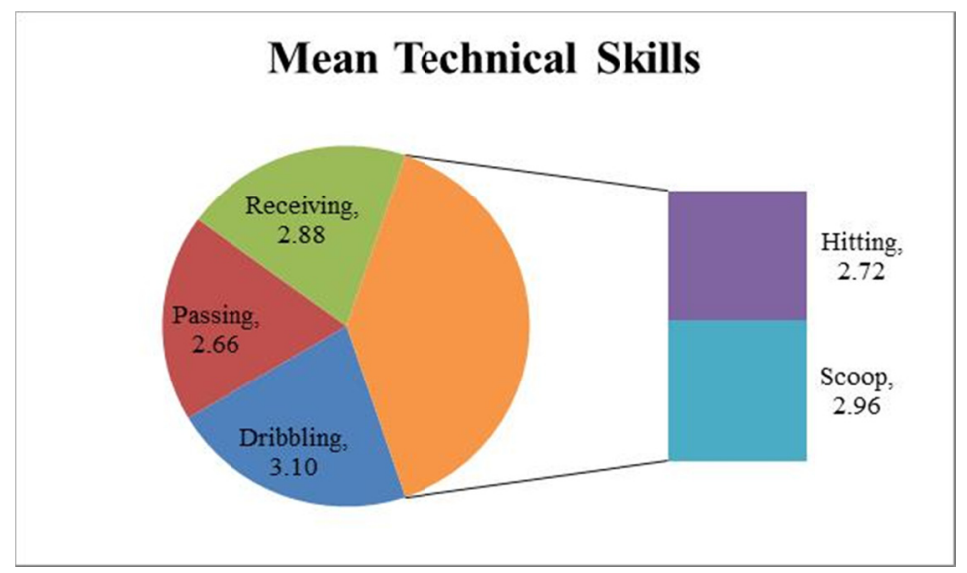

Figure 1. Illustrates the mean scores of technical skills of field hockey players

Of the 296 field hockey players at national sport departments of Pakistan, the mean score was calculated for technical skills of players in dribbling the ball (M, 3.10; SD, .635), passing the ball (M, 2.66; SD, .607), receiving the ball $(\mathrm{M}, 2.88 ; \mathrm{SD}, .749)$, hitting the ball (M, 2.72; SD, .633), and scoop the ball (M, 2.96; SD, .675) as shown in Table 5 and Figure 1above respectively.

Secondly, fitness capabilities in form of four (interval shuttle run test, linear speed test, agility test, and endurance capacity test) fitness measures were assessed in the fields of play through performance tests as an alternate instrument for data collection from the same respondents who participated in the survey questionnaire.

Table 6. Statistics fitness capabilities of field hockey players

\begin{tabular}{ccccc}
\hline & Interval Shuttle Run Test & Linear Speed Test & Agility Test & Endurance Capacity Test \\
\hline $\mathrm{N} \quad$ Valid & 296 & 296 & 296 & 296 \\
& 2.85 & 2.95 & 2.76 & 2.71 \\
Mean & .702 & .753 & .674 & .721 \\
\hline
\end{tabular}

Of the 296 players of field hockey belong to national sport departments of Pakistan, the mean and SD scores were presented for fitness capabilities in form of interval shuttle run test $(\mathrm{M}, 2.85 ; \mathrm{SD}, .702)$, linear speed test $(\mathrm{M}, 2.95 ; \mathrm{SD}, .753)$, agility test $(\mathrm{M}, 2.76 ; \mathrm{SD}, .674)$, and endurance capacity test $(\mathrm{M}, 2.71 ; \mathrm{SD}, .721)$ as shown in Table 6 above and Figure 2 below.

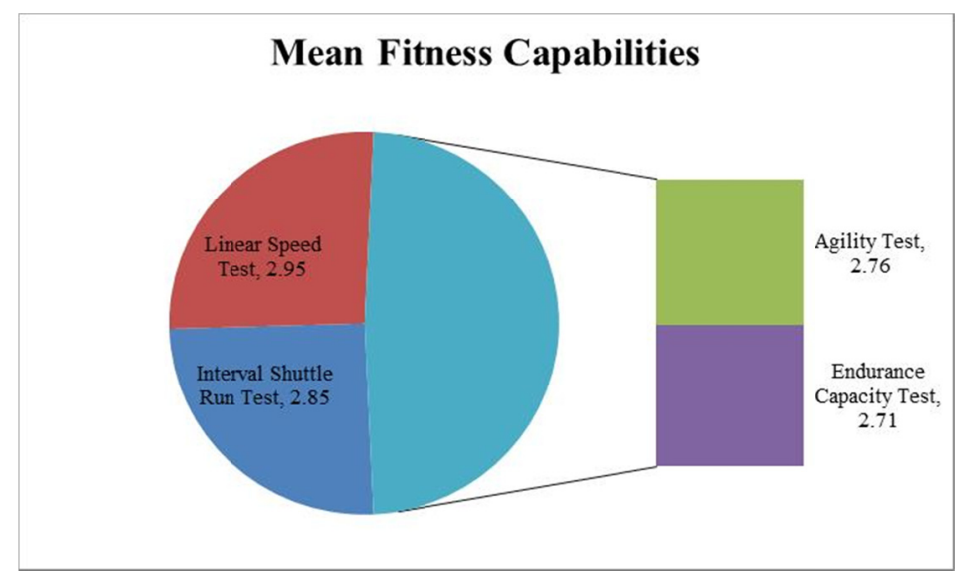

Figure 2. Depicts the mean scores of fitness capabilities of field hockey players 


\subsection{Baseline Data}

Demographic information of 296 respondents were composed and analyzed through descriptive (mean and standard deviation) statistics. Information comprised of players' age, field hockey departments, and education level. Analyses of demographic information are tabularized below.

Table 7. Participants age level

\begin{tabular}{cccccc}
\hline & N & Minimum & Maximum & Mean & Std. Deviation \\
\hline age level & 296 & 21 & 28 & 24.65 & 1.850 \\
Valid N (listwise) & 296 & & & & \\
\hline
\end{tabular}

A number of 296 respondents between 21 to 28 years of age level participated in the current study through the survey questionnaires. The mean age of the respondents was measured 24.65 years whereas standard deviation (SD) noted 1.850 as shown in Table 7 and year-wise age percentage of 296 respondents presented in Figure 3 below.

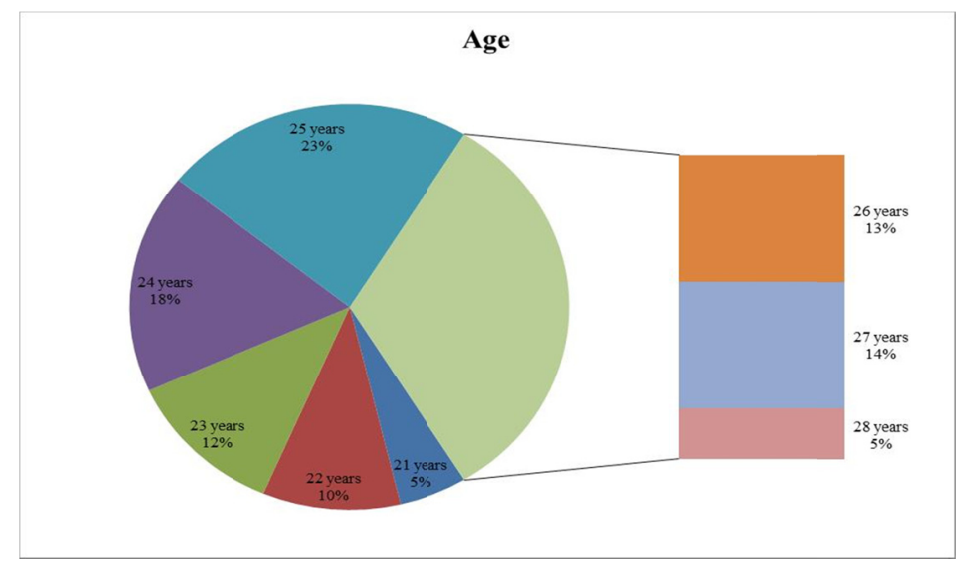

Figure 3. Illustrates the age level of the respondents

Education level among the national field hockey players of Pakistan was not up to the mark. The majority of the players (48\%) having matric education. However, 27\% from the overall 296 hockey players were found as FA/FSc/D.Com degree holders. A very little figure with $8 \%$ players only apprehended the degree of bachelor and $17 \%$ were under matric who had education below than matriculation as shown in Figure 4 below.

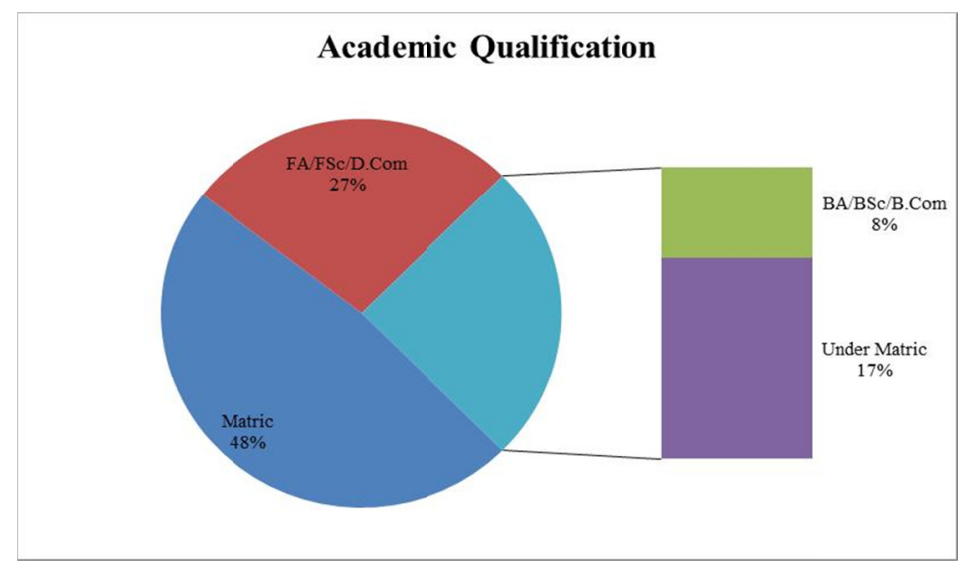

Figure 4. Highlights the academic qualification of the respondents 


\section{Discussion}

The one of the objectives of the current study was to examine the relationship of hockey coaches and team cohesion with the performance of field hockey players and secondly, to examine the relationship between predictor factors (hockey coaches and team cohesion) and the performance of field hockey players. Table 1 defines the relationships of hockey coaches and team cohesion with the performance of field hockey players. Grounded on these relationships, three (3) models of multiple regressions analysis were tested to know the influence of hockey coaches and team cohesion on tactical skills, interpersonal skills, and communicational skills of field hockey players (performance). However, two (2) hypotheses are placed forward for investigation.

Descriptive statistics are apparent that all field hockey players participated in current study ponder that they had been provided at least opportunities to improve the performance of tactical skills, interpersonal skills, communication skills, technical skills, and fitness capabilities. One may be the reason that due to low education level, players' intellectual level is not up to the mark that may affect their learning capabilities. The results of descriptive statistics showed that the field hockey players had some better tactical and interpersonal skills while they had moderate communicational skills perceived by field hockey players towards hockey coaches and team cohesion. On the other hand, the results about field performance tests of field hockey players exposed weaker in technical skills (dribbling, passing, receiving, hitting, and scoop) and fitness capabilities (interval shuttle run, linear speed, agility, and endurance capacity). Dribbling was only the skill in which players performed average. The overall skills of field hockey players were found low and did not meet the national standards and afterward international. This may be one of the reasons that field hockey players had been provided least opportunities of sport coaching to skills development from their departments. In conclusion, the results exposed concerning to the dimensions, the overall performance of five groups of skills up to moderately performed to weak performed. Tactical skills and interpersonal skills perceived to have been the average performed by field hockey players followed by communication skills. However, technical skills and fitness capabilities perceived to have been the least performed by field hockey players. The current results indicate that due to lack of technical skills and fitness capabilities, this may also be the reason of decline of Pakistani field hockey that the national players have not been performing well from the last two decades in national and international level competitions. Elferink-Gemser, Kannekens, Lyons, Tromp, and Visscher (2010) indicated the skills in their field hockey study as the awareness concerning in-game modifications and decision-making movements on the playground during the course of the game/match. Hence, the results propose that current and future field hockey development struggles should concentrate on competency measures of tactical skills, communicational skills, technical skills, and fitness capabilities in specific performance context.

The results presented in Table 1 exposed that the relationship between hockey coaches and the performance of Pakistani national field hockey players revealed positive and highly significant ( $p=0.01,2$-tailed). The findings of hockey coaches to performance of players are associated with the prior studies (Dirks, 2000; Manning, 2007; Moen \& Federici, 2013), those are verified empirically. A very few studies on poor performance of coaches are existed. Reddy, Babu, and Kidane (2013) exposed the reasons of poor relationship between coach and athlete that are related to dearth of mutual respect, no tangible gratitude for whichever person's character maybe of all these are utmost serious and deficiency of trustworthiness between coach and athlete during their communication when does take place. The relationship between team cohesion and the performance of Pakistani national field hockey players exposed positive and highly significant $(p=0.01,2$-tailed). Carron \& Chelladurai (1981) affirmed in their study that constant communication among all team members improves the victory of the sport team like hockey team. The findings of the study by Carron, Bray, and Eys (2002) provided the evidence of a strong association of cohesion among players to success in sport teams. Therefore, $\mathrm{H} 1$ is accepted by the data.

The results of model summary and coefficients of multiple regressions Analyses (Model 1,2,3) as shown in Table 1a, Table $1 \mathrm{~b}$, Table $2 \mathrm{a}$, Table $2 \mathrm{~b}$, Table $3 \mathrm{a}$, and Table $3 \mathrm{~b}$ respectively revealed that hockey coaches and team cohesion had positively and significantly $(p=0.05)$ impact on tactical skills (Model 1$)$, interpersonal skills (Model 2), and communicational skills (Model 3) of field hockey players (performance). Vella, Oades, and Crowe (2010) confirmed in their study that the coach's individual features and coach behaviors affect the players' performance. A study conducted by Kenow and Williams (1999) disclosed that coaches in general have a great impression on the performance because of arranging the practice, characteristics, expertise, leadership, and communicating the players while in or out the practice environment. On the other hand, a study conducted by Chang et al. (2006) revealed that cohesion among players and performance would enhance over time. Carron et al., (2003) study findings exposed that teammates are further to be expected to expose greater compromise approximately for their team's cohesiveness when they observe about cohesiveness to be better. Therefore, $\mathrm{H} 2$ is accepted by the data. 
The finding of current study showed that there is need to increase the accessibility of practicing resources by Pakistani field hockey institutions. However, any commitment through sport authorities to promote their players learning practices collectively comprise of tactical skills, interpersonal skills, communicational skills, technical skills, and fitness capabilities may encourage field hockey players to develop their skills competencies and cohesiveness among players. This could be through facilitating sufficient infrastructure and modern technology for practical skills of field hockey players because the world field hockey is converting from manual system to digital technology. This describes why Pakistani field hockey departments should try their best in developing their infrastructure furnished with important practicing resources so that sufficient training would be delivered to field hockey players.

The main implication of the study is the need for professional coaching clinics/courses to develop field hockey coaching knowledge of departmental coaches and how these rudiments improve the practicing and coaching procedures and competency improvement in field hockey players. Consciousness of and concentrate on competency improvement in players as practice goals could help sport authorities to recognize the probable modifications. Sport authorities should concern that communicating knowledge and increasing the expertise of hockey coaches needed in today's energetic field hockey setting. Coaching clinics could be fortified to promote coaches' progress that highlight the importance of recognizing competences for real coaching to upsurge hockey knowledge of how the coaching competences may impact or hinder their players learning practices. The management of field hockey departments should provide more consideration to the expand the relationship of hockey coaches and team cohesion among players to enhance the performance and bring the past glories of the game back in Pakistan.

\section{References}

Alemu, S. M., \& Babu, M. S. (2012). The relationship between coaches' leadership styles, team cohesion and team success: the case of premier league soccer clubs in Ethiopia. International Journal of Social Science \& Interdisciplinary Research, 1(11), 1-13.

Ali, M. (2015, July 7). Sardar Naved vows to revive Pakistan hockey. The Nation. Retrieved from http://www. awaztoday.tv/News_Sardar-Naved-vows-to-revive-Pakistan-hockey_2_58704_Sports-News.aspx

Aoyagi, M. W., Cox, R. H., \& McGuire, R. T. (2008). Organizational citizenship behavior in sport: Relationships with leadership, team cohesion, and athlete satisfaction. Journal of Applied Sport Psychology, 20, 25-41. http://dx.doi.org/10.1080/10413200701784858

Asghar, E. (2011). A comparative study of multidimensional talent in field hockey at development stage between the players of Germany and Pakistan (Doctoral dissertation, University of Leipzig, Germany). Retrieved from http://library.gcu.edu.pk/Thesis/PhD/GCUFAC-18.pdf

Beal, D. J., Cohen, R. R., Burke, M. J., \& McLendon, C. L. (2003). Cohesion and performance in groups: A meta-analytic clarification of construct relations. Journal of Applied Psychology, 88(6), 989-1004. http://dx.doi.org/10.1037/0021-9010.88.6.989

Bhatti, A. S. (2013, August 31). The most shameful defeat in the history of Pakistan hockey. The Express Tribune. Retrieved from http://blogs.tribune.com.pk/story/18692/the-most-shameful-defeat-in-the-history-of-pakista n-hockey/

Brawley, L. R., Carron, A. V., \& Widmeyer, W. N. (1993). The influence of the group and its cohesiveness on perceptions of group goal-related variables. Journal of Sport \& Exercise Psychology, 15, 245-260.

Bray, C. D., \& Whaley, D. E. (2001). Team cohesion, effort, and objective individual performance of high school basketball players. The Sport Psychologist, 15, 260-275.

Carron, A. V., \& Chelladurai, P. (1981). Cohesiveness as a factor in sport performance. International Review for the Sociology of Sport, 16(2), 21-43. http://dx.doi.org/10.1177/101269028101600202

Carron, A. V., Brawley, L. R., \& Widmeyer, W. N. (1998). The measurement of cohesiveness in sport groups. In J. L. Duda (Ed.), Advances in sport and exercise psychology measurement (pp. 213-226). Morgantown, WV: Fitness Information Technology.

Carron, A. V., Brawley, L. R., Eys, M. A., Bray, S., Dorsch, K., Estabrooks, P., ... Terry, P. C. (2003). Do individual perceptions of group cohesion reflect shared beliefs? An empirical analysis. Small Group Research, 34, 468-496. http://dx.doi.org/10.1177/1046496403254274

Carron, A. V., Bray, S. R., \& Eys, M. A. (2002). Team cohesion and team success in sport. Journal of Sports Sciences, 20, 119-126. http://dx.doi.org/10.1080/026404102317200828 
Carron, A. V., Colman, M. M., Wheeler, J., \& Stevens, D. (2002). Cohesion and performance in sport: A mata analysis. Journal of Sport and Exercise Psychology, 24, 168-188.

Carron, A. V., Widmeyer, W. N., \& Brawley, L. R. (1985). The development of an instrument to assess cohesion in sport teams: The group environment questionnaire. Journal of Sport Psychology, 7, 244-266.

Chang, A., Duck, J., \& Bordia, P. (2006). Understanding the multidimensionality of group development. Small Group Research, 37(4), 327-350. http://dx.doi.org/10.1177/1046496406290564

Chelladurai, P., \& Saleh, S. D. (1980). Dimensions of leader behavior in sports: Development of a leadership scale. Journal of Sport Psychology, 2, 34-45.

Cohen, L., Manion, L., \& Morrison, K. (2007). Research methods in education (6th ed.). London: Routledge.

Cottingham, M. P., Blom, L. C., Burchell, S. H., \& Johnson, J. T. (2010). Understanding the relationships among social cohesion, the coach-athlete relationship, and socioeconomic status of high school softball and baseball players. Journal for the Study of Sports and Athletes in Education, 4(1), 9-21. http://dx.doi.org/10. 1179/ssa.2010.4.1.9

DeWeese, B. H. (2012). Defining the constructs of expert coaching: A Q-methodological study of Olympic sport coaches (Doctoral dissertation, North Carolina State University). Retrieved from https://www.google. $\mathrm{com} /$ search client $=$ opera \& $=$ Defining + the + Constructs + of + Expert + Coaching $\% 3 \mathrm{~A}+\mathrm{A}+\mathrm{QMethodological}+\mathrm{S}$ tudy + of + OlympicSport + Coaches + pdf\&sourceid $=$ opera $\&$ ie $=U$ UTF- $8 \&$ oe $=U T F-8$

Dirks, K. T. (2000). Trust in leadership and team performance: Evidence from NCAA basketball. Journal of Applied Psychology, 85(6), 1004-1012. http://dx.doi.org/10.1037//0021-90I0.85.6.1004

Elferink-Gemser, M. T., Kannekens, R., Lyons, J., Tromp, Y., \& Visscher, C. (2010). Knowing what to do and doing it: Differences in self-assessed tactical skills of regional, sub-elite, and elite youth field hockey players. Journal of Sports Sciences, 28(5), 521-528. http://dx.doi.org/10.1080/02640410903582743

Elferink-Gemser, M. T., Visscher, C., Lemmink, K. A. P. M., \& Mulder, T. (2007). Multidimensional performance characteristics and standard of performance in talented youth field hockey players: a longitudinal study. Journal of sports sciences, 25(4), 481-899. http://dx.doi.org/10.1080/0264041060071 9945

Eys, M., Ohlert, J., Evans, M. B., Wolf, S. A., Martin, L. J., Bussel, M V., \& Steins, C. (2015). Cohesion and performance for female and male sport teams. The Sport Psychologist, 29, 97-109. http://dx.doi.org/10. 1123/tsp.2014-0027

Forsyth, D. R. (2010). Group dynamics (5th ed.). Belmont, CA: Wadsworth, Cengage Learning

Haq, H. (2013, July 21). Preparing for the hockey World cup. The Express Tribune. Retrieved from http:/tribune.com.pk/story/579961/preparing-for-the-hockey-world-cup/

Hoption, C., Phelan, J., \& Barling, J. (2007). Transformational leadership in sport. In M. R. Beauchamp, \& M. A. Eys (Eds.), Group dynamics in exercise and sport psychology: Contemporary themes (pp. 45-60). Abingdon, Oxon: Routledge.

Jacob, C. S., \& Carron, A. V. (1998). The association between status and cohesion in sport teams. Journal of Sports Sciences, 16, 187-198. http://dx.doi.org/10.1080/026404198366894

Jowett, S. (2005). The coach-athlete partnership. The Psychologist, 18(7), 412-415.

Jowett, S. (2007). Coach-athlete relationships ignite sense of groupness. In M. R. Beauchamp, \& M. A. Eys (Eds.), Group dynamics in exercise and sport psychology: Contemporary themes (pp. 63-77). Abingdon, Oxon: Routledge.

Jowett, S., \& Chaundy, V. (2004). An investigation into the impact of coach leadership and coach-athlete relationship on group cohesion. Group Dynamics: Theory, Research, and Practice, 8(4), 302-311. http://dx.doi.org/10.1037/1089-2699.8.4.302

Kanchan, Singh, R., \& Tarandeep. (2012). Relationship between team cohesion and performance in ball games. VSRD Technical \& Non-Technical Journal, 3(5), 191-196.

Kenow, L., \& Williams, J. M. (1999). Coach-athlete compatibility and athlete's perception of coaching behaviors. Journal of Sport Behavior, 22(2), 251-258.

Khalaj, G., Khabiri, M., \& Sajjadi, N. (2011). The relationship between coaches' leadership styles \& player satisfaction in women skate championship. Procedia Social and Behavioral Sciences, 15, 3596-3601. 
http://dx.doi.org/10.1016/j.sbspro.2011.04.341

Krejcie, R. V., \& Morgan, D. W. (1970). Determining sample size for research activities. Educational and Psychological Measurement, 30, 607-610. http://dx.doi.org/10.1177/001316447003000308

Manning, C. T. (2007). Relationship among team collective efficacy, cohesion, and coaching competency in sports (Doctoral dissertation). Utah State University. Retrieved from http://search.proquest.com/docview/ 304469916? accountid=13155. (304469916).

Martin, L. J., Paradis, K. F., Eys, M. A., \& Evans, B. (2013). Cohesion in sport: New directions for practitioners. Journal of Sport Psychology in Action, 4, 14-25. http://dx.doi.org/10.1080/21520704.2012.702710

Meulmana, H. N., Berger, M. A. M., Zande, M. E., Kok, P. M., Ottevanger, E. J. C., \& Crucq, M. B. (2012). Development of a tool for training the drag flick penalty corner in field hockey. Procedia Engineering 34, 508-513. http://dx.doi.org/10.1016/j.proeng.2012.04.087

Moen, F., \& Federici, R. A. (2013). Coaches' coaching competence in relation to athletes' perceived progress in elite sport. Journal of Education and Learning, 2(1), 240-252. http://dx.doi.org/10.5539/jel.v2n1p240

Mohd Zainal, M. H., \& Rosli, M. (2012). The relationship between group cohesiveness and performance: An empirical study of cooperatives movement in Malaysia. International Journal of Cooperative Studies, 1(1), $15-20$.

Muijs, D. (2011). Doing qualitative research in education with SPSS (2nd ed.). London, Thousand Oaks: sage Publications.

Mullen, B., \& Copper, C. (1994). The relation between group cohesiveness and performance: An integration. Psychological Bulletin, 115, 210-227. http://dx.doi.org/10.1037/0033-2909.115.2.210

Murray, N. P. (2006). The differential effect of team cohesion and leadership behavior in high school sports. Individual Differences Research, 4(4), 216-225.

Pakistan Hockey Federation (PHF). Retrieved from http://www.nocpakistan.org/sportsfederations.php?sptid= 13\#goto

Ramzaninezhad, R., \& Keshtan, M. H. (2009). The relationship between coach's leadership styles and team cohesion in Iran football clubs professional league. Brazilian Journal of Biomotricity, 3(2), 111-120.

Reddy, C., Babu, S. M., \& Kidane, W. W. (2013). The effect of coaching behavior on player's satisfaction in the case of Ethiopian soccer players: Review of literature. International Journal of Social Science \& Interdisciplinary Research, 2(1), 106-117.

Shapcott, K. M., Carron, A. V., Greenlees, I., \& El-Hakim, Y. (2010). Determinants of team-referent attributions: A multilevel analysis. IJSEP, 8, 227-244. http://dx.doi.org/10.1080/1612197X.2010.9671951

Tabachnick, B. G., \& Fidell, L. S. (2001). Using multivariate statistics (4th ed.). New York: HarperCollins.

Thiel, D. V., Tremaynea, M., \& James, D. A. (2012). Monitoring stick speed and ball control in field hockey drills using a stick-mounted inertial accelerometer. Procedia Engineering, 34, 574-579. http://dx.doi.org/10.1016/j.proeng.2012.04.098

Turman, P. D. (2008). Coaches' immediacy behaviors as predictors of athletes' perceptions of satisfaction and team cohesion. Western Journal of Communication, 72(2), 162-179. http://dx.doi.org/10.1080/1057031080 2038424

Vella, S., Oades, L. G., \& Crowe, T. P. (2010). The application of coach leadership models to coaching practice: Current state and future directions. International Journal of Sports Science and Coaching, 5(3), 425-434. http://dx.doi.org/10.1260/1747-9541.5.3.425

Vincer, D. J. E., \& Loughead, T. M. (2010). The relationship among athlete leadership behaviors and cohesion in team sports. The Sport Psychologist, 24, 448-467.

Westre, K. R., \& Weiss, M. R. (1991). The relationship between perceived coaching behaviors and group cohesion in high school football teams. The Sport Psychologist, 5, 41-54.

Williams, J. M., \& Widmeyer, W. N. (1991). The cohesion-performance outcome relationship in a coacting sport. Journal of Sport \& Exercise Psychology, 13, 364-371. http://dx.doi.org/10.1016/j.ijintrel.2013.05.001

Yaqoob, M. (2013, August 31). Missed chances led to defeat. Dawn. Retrieved from http://www.dawn.com/ news/1039442/missed-chances-led-to-defeat-says-akhtar-rasool 
Zaman, T. (2013, December 15). Pakistan India need strong development programs. The Nation. Retrieved from http://www.nation.com.pk/sports/15-Dec-2013/pakistan-india-need-strong-development-programmes-tahir

Zaman, T. (2015, July, 6). Hockey debacle was certain. Down. Retrieved from http://www.dawn.com/news/ 1192552/hockey-debacle-was-certain-tahir-zaman

Zuberi, A. (2015, July 4). Comment: Humiliation and disqualification - Pakistan hockey's darkest hour. Dawn. Retrieved from http://www.dawn.com/news/1192138/comment-humiliation-and-disqualification-pakistanhockeys-darkest-hour

\section{Copyrights}

Copyright for this article is retained by the author(s), with first publication rights granted to the journal.

This is an open-access article distributed under the terms and conditions of the Creative Commons Attribution license (http://creativecommons.org/licenses/by/3.0/). 